\title{
A View of Antarctic Ice-Sheet Evolution from Sea-Level and Deep-Sea Isotope Changes During the Late Cretaceous-Cenozoic
}

\author{
K. G. Miller, ${ }^{l}$ J. D. Wright,$^{l}$ M. E. Katz, ${ }^{1,2}$ J. V. Browning, ${ }^{l}$ \\ B. S. Cramer, ${ }^{3}$ B. S. Wade, ${ }^{4}$ S. F. Mizintseval
}

\begin{abstract}
The imperfect direct record of Antarctic glaciation has led to the delayed recognition of the initiation of a continentsized ice sheet. Early studies interpreted initiation in the middle Miocene (ca $15 \mathrm{Ma}$ ). Most current studies place the first ice sheet in the earliest Oligocene (33.55 Ma), but there is physical evidence for glaciation in the Eocene. Though there are inherent limitations in sea-level and deep-sea isotope records, both place constraints on the size and extent of Late Cretaceous to Cenozoic Antarctic ice sheets. Sealevel records argue that small- to medium-size (typically $10-12 \times 10^{6} \mathrm{~km}^{3}$ ) ephemeral ice sheets occurred during the greenhouse world of the Late Cretaceous to middle Eocene. Deep-sea $\delta^{18} \mathrm{O}$ records show increases associated with many of these greenhouse sea-level falls, consistent with their attribution to ice-sheet growth. Global cooling began in the middle Eocene and culminated with the major earliest Oligocene $(33.55 \mathrm{Ma})$ growth of a large $\left(25 \times 10^{6} \mathrm{~km}^{3}\right)$ Antarctic ice sheet that caused a $55-70 \mathrm{~m}$ eustatic fall and a $1 \% \circ \delta^{18} \mathrm{O}$ increase. This large ice sheet became a driver of climate change, not just a response to it, causing increased latitudinal thermal gradients and a spinning up of the oceans that, in turn, caused a dramatic reorganization of ocean circulation and chemistry.
\end{abstract}

${ }^{1}$ Department of Earth and Planetary Sciences, Rutgers University, Piscataway, NJ 08854, USA.

${ }^{2}$ Earth \& Environmental Sciences, Rensselaer Polytechnic Institute, Troy, NY 12180, USA.

${ }^{3}$ Department of Geological Sciences, University of Oregon, Eugene, OR 97403, USA.

${ }^{4}$ Now at Department of Geology \& Geophysics, Texas A\&M University, College Station, TX 77843, USA.

\section{INTRODUCTION}

Glacial sediments on the Antarctic continent and its margins (Figure 1) (Barrett, 2007; Barrett et al., 1987; Birkenmajer et al., 2005; Cooper et al., forthcoming; Cooper and O'Brien, 2004; Ivany et al., 2006; Kennett and Barker, 1990; Leckie and Webb, 1986; LeMasurier and Rex, 1982; Strand et al., 2003; Troedson and Riding, 2002; Troedson and Smellie, 2002; Zachos et al., 1992) provide a direct record of ice sheets, but these records are temporally incomplete and often poorly dated and thus may not provide a complete and unequivocal history, especially of initiation of ice sheets. Deep-sea $\delta^{18} \mathrm{O}$ records (Figures 1 and 2) provide well-dated evidence for changes in temperature and $\delta^{18} \mathrm{O}_{\text {seawater }}$ due to ice-sheet growth, but separating these two effects is difficult (e.g., Miller et al., 1991). Global sea-level records provide evidence for large (tens of meters), rapid ( $<1 \mathrm{myr}$ ) changes in sea level (Figure 2) that can be explained only by changes in continental ice sheets, though the amplitudes of the changes have been poorly constrained until recently (Miller et al., 2005a). Each of these methods has its limitations, but by integrating results from all three we can begin to decipher the history of Antarctic ice sheets.

Over the past 30 years, study of glacial sediments and stable isotopes has progressively extended the initiation of ice sheets further back in time. For example, consider the history of Northern Hemisphere ice sheets (NHISs), better known as the "Ice Ages." Glacial deposits formed during advances of Laurentide ice led to the mistaken concept of only four Pleistocene glaciations (Flint, 1971), one that was eventually contradicted by deep-sea $\delta^{18} \mathrm{O}$ records showing that there were: 


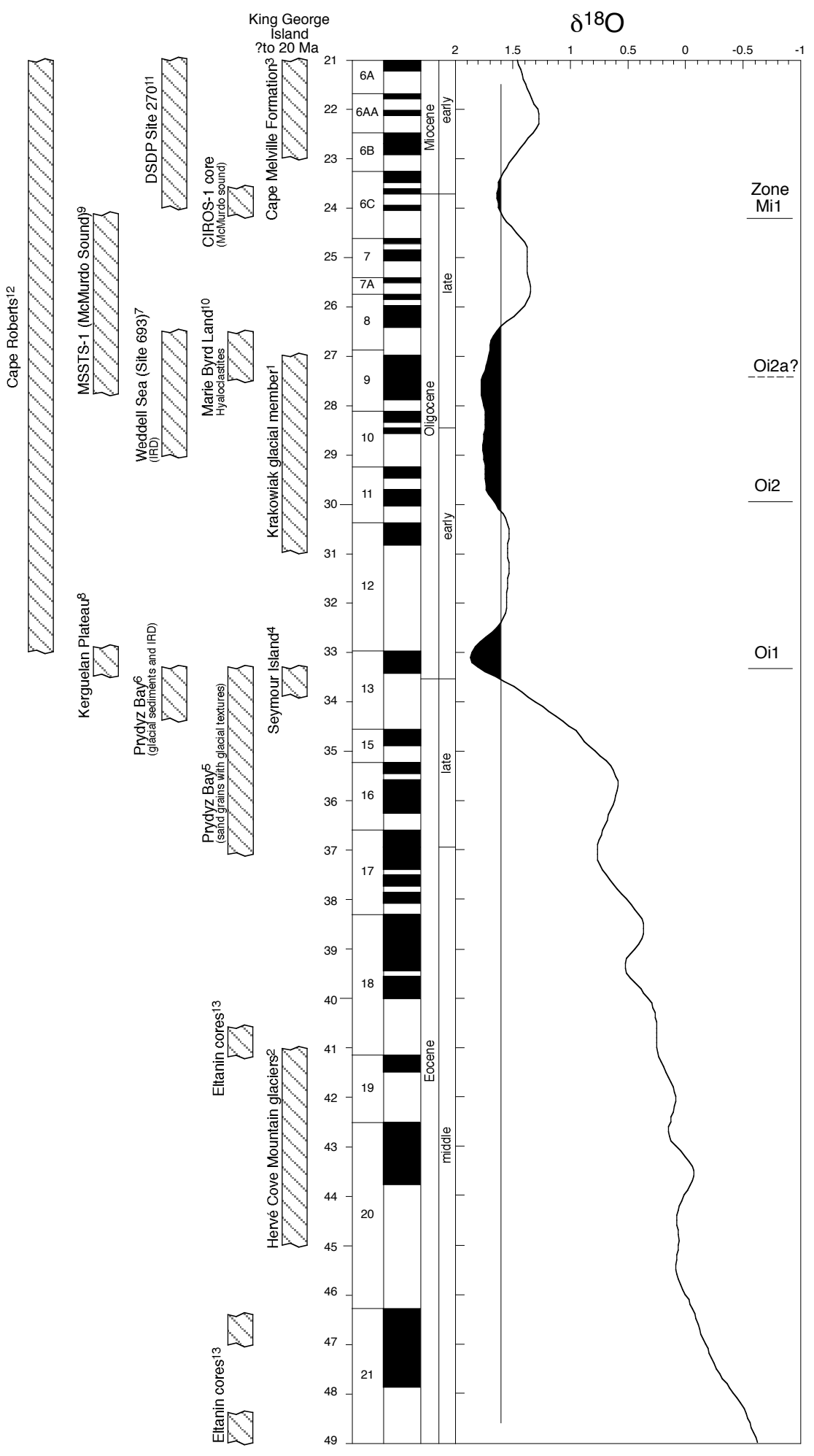

FIGURE 1 Oligocene benthic foraminiferal synthesis compared with the record of glaciomarine sediments (modified from Miller et al., 1991). Benthic foraminiferal stable isotope data were stacked and smoothed with a Gaussian convolution filter in order to remove periods less than 1.0 myr. Because filtering dampens the amplitude, an arbitrary line was placed through $1.6 \%$ and values higher than this were shaded. 1. Troedson and Smellie (2002); 2. Birkenmajer et al. (2005); 3. Troedson and Riding (2002); 4. Ivany et al. (2006); 5. Strand et al. (2003); 6. Cooper and O'Brien (2004); 7. Kennett and Barker (1990); 8. Zachos et al. (1992); 9. Barrett et al. (1987); 10. LeMasurier and Rex (1982); 11. Leckie and Webb (1986); 12. Barrett (2007). 


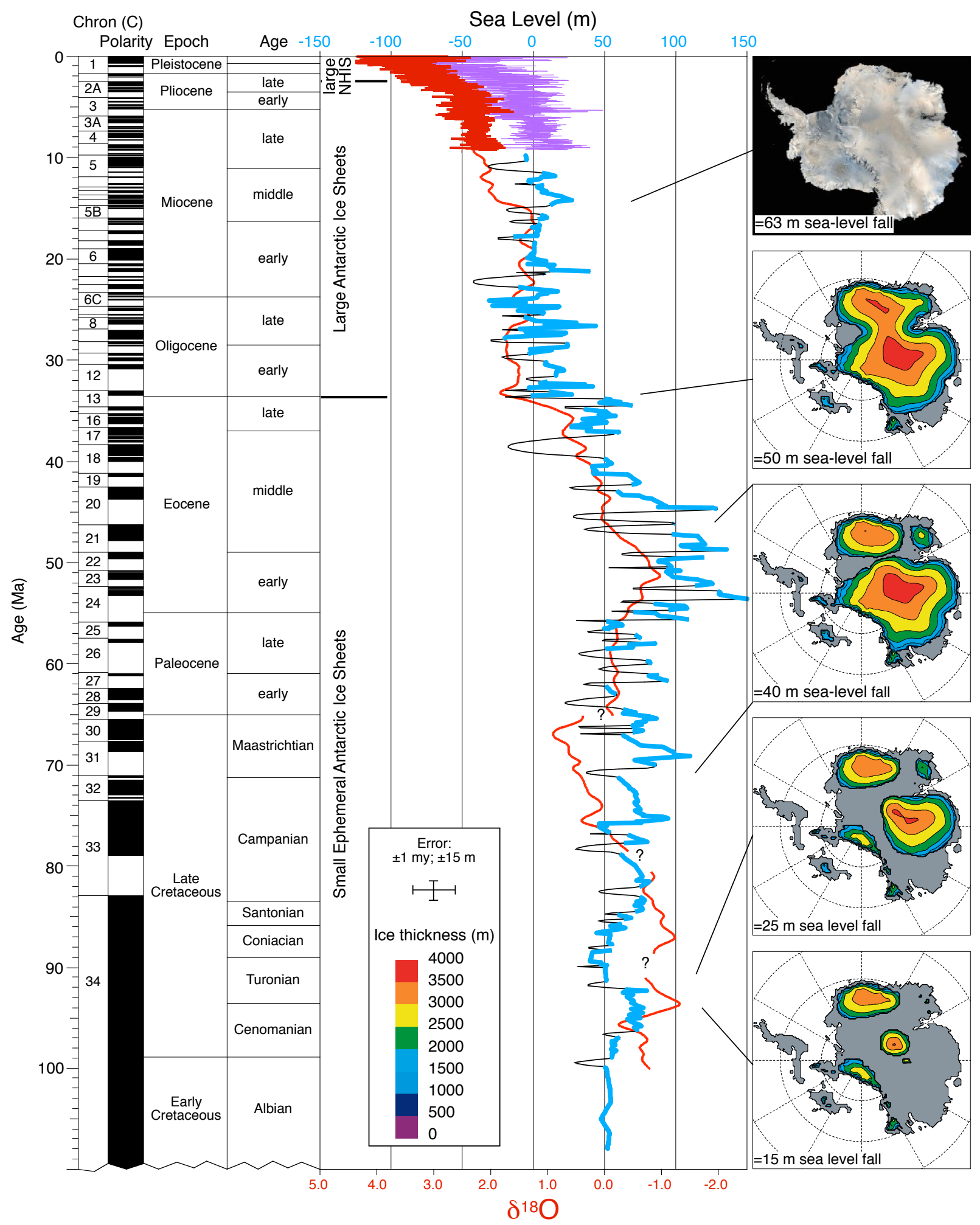

FIGURE 2 Global sea level (light blue) for the interval 7-100 Ma derived by new backstripped estimates; lowstands are indicated with thin black lines and are unconstrained by data (Miller et al., 2005a). Global sea level (purple) for the interval 0-7 Ma derived from $\delta^{18} \mathrm{O}$ after Miller et al. (2005a). Shown for comparison is a benthic foraminiferal $\delta^{18} \mathrm{O}$ synthesis from 0-100 Ma (red curve) with scale on bottom axis in \%o (reported to Cibicidoides values [0.64\%o lower than equilibrium]). The portion of the $\delta^{18} \mathrm{O}$ curve from $0-65 \mathrm{Ma}$ is derived using data from Miller et al. (1987); the Late Cretaceous synthesis is after Miller et al. (2004). Data from 7-100 Ma were interpolated to constant 0.1 myr interval and smoothed with a 21-point Gaussian convolution filter using Igor Pro ${ }^{\text {TM }}$. Timescale of Berggren et al. (1995). Maps showing maximum sizes of ice sheets during peak glaciation for several intervals. Maps are after DeConto and Pollard (2003a,b) and show the amount of equivalent sea-level change proscribed for a given state (e.g., $25 \mathrm{~m}$ ) and are calibrated to the $\delta^{18} \mathrm{O}$ synthesis (correlation lines) using sea-level data. 
1. Eight large ( 120 m sea-level lowerings), 100-kyrscale ice ages over the past $800 \mathrm{kyr}$;

2. Sixty-two stages ${ }^{5}$ representing 31 ice-sheet advances on $\sim 20-, 41-$, and $\sim 100-\mathrm{kyr}$-scale during the Pleistocene; and

3. Over 100 named stages and 50 glacial advances since the late Pliocene "initiation" of NHIS (Emiliani, 1955; Hays et al., 1976; Shackleton, 1967).

A pulse of ice-rafted detritus (IRD) into the northern North Atlantic ca. 2.6 Ma (late Pliocene) is associated with a major $\delta^{18} \mathrm{O}$ increase; this has been interpreted as the inception of NHISs (Shackleton et al., 1984). However, this inception reflects not initiation but an increase in the size of NHISs growth and decay (e.g., Larsen et al., 1994). Significant (at least Greenland-size) NHISs extend back at least to the middle Miocene (ca. 14 Ma; see summary in Wright and Miller, 1996) and recent data indicate that large NHISs may have existed since the middle Eocene (Eldrett et al., 2007; Moran et al., 2006).

The imperfect direct record of Antarctic glaciation has similarly led to the progressive extension of initiation of a continent-size ice sheet from $15 \mathrm{Ma}$ (middle Miocene) back to $33.55 \mathrm{Ma}$ (earliest Oligocene) (see summaries in Miller et al., 1991, 2005a,b; Zachos et al., 1996). In this contribution we suggest that continental ice sheets have been intermittently present on Antarctica through the Late Cretaceous, a time when Antarctica took up residence at the pole (http:// www.ig.utexas.edu/research/projects/plates/).

Deep-sea isotope records have long been used to interpret Antarctic ice-sheet history. Based on deep-sea $\delta^{18} \mathrm{O}$ records, early studies of Shackleton and Kennett (1975) and Savin et al. (1975) assumed that a continent-size ice sheet first appeared in Antarctica in the middle Miocene (ca. $15 \mathrm{Ma}$ ), though they noted that glaciation (in the form of mountain glaciers and sea ice) probably occurred back through the Oligocene. Also using isotope data, Matthews and Poore (1980) suggested that large ice sheets existed in Antarctica since at least the earliest Oligocene (33.5 Ma). The differences in interpretation partly illustrate problems in using $\delta^{18} \mathrm{O}$ as an ice-volume proxy, because deep-sea $\delta^{18} \mathrm{O}$ values also reflect deep-water temperature changes that generally mimic high-latitude surface temperatures. Miller and Fairbanks $(1983,1985)$ and Miller et al. (1987, 1991) provided the strongest isotopic evidence for the presence of ice sheets during the Oligocene; high $\delta^{18} \mathrm{O}$ values measured in deep-sea cores ( $>1.8 \%$ in Cibicidoides spp. or $>2.4 \%$ in Uvigerina spp.) require bottom-water temperatures colder than today if an ice-free world is assumed. Such low bottom-water temperatures are incompatible with an icefree world; their isotopic synthesis (updated and presented

\footnotetext{
${ }^{5}$ Although called "oxygen isotopic stages" by paleoceanographers for decades, the term "stage" is a stratigraphic term reserved for characterizing time-rock units (Hedberg, 1976). The proper term for "isotopic variations" are "zones in depth and chrons in time."
}

in Figures 1 and 2) suggest at least three major periods of Oligocene glaciation.

A campaign of drilling near Antarctica by the Ocean Drilling Program (ODP) in the late 1980s returned firm evidence that supported the $\delta^{18} \mathrm{O}$ record for large ice sheets in the earliest Oligocene that included grounded tills and IRD at lower latitudes than today (see summaries by Miller et al., 1991; Zachos et al., 1992). We update the summary of the direct evidence for Eocene-Oligocene ice in the form of tills and glaciomarine sediments near the Antarctic (Figure 1), using more recent drilling by ODP (Cooper and O'Brien, 2004; Strand et al., 2003), the Cape Roberts drilling project (Barrett, 2007), plus studies that extend West Antarctic glaciation back through the early Oligocene (Seymour Island) (Ivany et al., 2006) and into the Eocene (King George Island; Birkenmajer et al., 2005; Troedson and Riding, 2002; Troedson and Smellie, 2002). The evidence for large, grounded ice sheets begins in the earliest Oligocene and continues through the Oligocene (Figure 1). Seismic stratigraphic studies summarized by Cooper et al. (forthcoming) also show intense glacial activity beginning in the Oligocene in both East and West Antarctica. There is excellent agreement among proxies that Antarctica was in fact an icehouse during the Oligocene and younger interval. Ice-volume changes have been firmly linked to global sea-level changes in the Oligocene and younger "icehouse world" of large, varying ice sheets (Miller et al., 1998); Pekar et al. $(1996,2002)$ recognized that the three to four major Oligocene glaciations of Miller et al. (1991) in fact reflected six myr-scale sea-level falls and attendant ice-growth events. The record of glaciomarine sediments documents that the ice sheets occurred in Antarctica (Figure 1), though an NHIS component cannot be precluded due to scarce Northern Hemisphere Oligocene records. Today $33.5 \mathrm{Ma}$ is cited as the inception of the Antarctic ice sheet, though this supposition is now being challenged and pushed back into the Cretaceous (Miller et al., 1999, 2003, 2005a,b; Stoll and Schrag, 1996). Nevertheless, $33.55 \mathrm{Ma}$ was probably the first time in the past 100 myr that the ice sheets reached the coast, allowing large icebergs to calve and reach distal locations such as the Kerguelen Plateau (Figure 1) (ODP Site 748) (Zachos et al., 1992).

There is evidence for glaciation in the older Antarctic record. Coring by ODP Legs 119 and 120 (Barron and Larsen, 1989; Breza and Wise, 1992) and seismic stratigraphic studies (Cooper et al., forthcoming) suggest the possibility of late Eocene (or even possibly middle Eocene) glaciers in Prydz Bay. Seismic stratigraphic studies (Cooper et al., forthcoming) also suggest the possibility of late Eocene glaciers in the Ross Sea. Other studies extend the record for West Antarctic glaciation back from $10 \mathrm{Ma}$ to $45 \mathrm{Ma}$ (Birkenmajer, 1991; Birkenmajer et al., 2005). Though Birkenmajer et al. (2005) interpreted the Eocene tills as evidence for mountain glaciers and not necessarily ice sheets, it points to the likelihood that the continental interior could have supported an ice sheet 
in the middle Eocene. Margolis and Kennett (1971), Wei (1992), and Wise et al. (1991) interpreted middle Eocene quartz grains in Eltanin cores from near Antarctica as reflecting IRD (Figure 1), though the evidence of this as IRD versus other transport mechanisms is not compelling.

Early studies recognized the importance of a cold, if not fully glaciated, Antarctica on deep-water circulation (Kennett, 1977; Kennett and Shackleton, 1976; Shackleton and Kennett, 1975). Kennett (1977) attributed the EoceneOligocene transition to the development of a nascent Antarctic Circumpolar Current that caused thermal isolation of Antarctica, development of sea ice (though not continentalscale glaciation), and an increase in Antarctic bottom water (AABW). The formation of AABW today is particularly sensitive to sea ice, and geologic evidence is clear that an erosional pulse of deep water in the Southern Ocean occurred near the Eocene-Oligocene transition (Kennett, 1977; Wright and Miller, 1996). It was also known that a major drop in the calcite compensation depth (CCD) occurred across the Eocene-Oligocene transition (van Andel, 1975) in concert with this change in deep-water circulation. However, our understanding of deep-water history and its relationship to the evolution of Antarctic ice volume has been unclear in part because of uncertainties in the proxies for deep water and continental ice sheets.

Here we review interpretations of Antarctic ice-volume changes using sea-level and oxygen isotopic records. Using recently published sea-level curves (Kominz et al., in review;
Miller et al., 2005a) and published isotope data (Figures 2 and 3), we argue for the likely presence of small- to mediumsize ephemeral ice sheets in the greenhouse world of the Late Cretaceous to Eocene. Though there were ephemeral ice sheets in the greenhouse world, the Eocene-Oligocene transition represented the beginning of the icehouse with the largest cooling event of the last 100 myr, one that resulted in an ice sheet that reached the coast for the first time. We review published and recently submitted evidence for the nature and timing of paleoceanographic changes associated with the Eocene-Oligocene transition (Figure 4) and present new and published comparisons of global deep-water changes that resulted from this glaciation and attendant cooling (Figures 4 and 5).

\section{THE CASE FOR ICE SHEETS IN THE GREENHOUSE WORLD (CRETACEOUS-EOCENE)}

The sea-level curves of Exxon Production Research Company (EPR) (Haq et al., 1987; Vail et al., 1977) stimulated interest in large, rapid, global sea-level changes. Vail et al. (1977) reported numerous large (>100 m) Phanerozoic sealevel falls, including a $400 \mathrm{~m}$ drop in mid-Oligocene. On the Vail curve these falls were shown as virtually instantaneous. Subsequent study showed that this saw-toothed pattern with extremely rapid falls was an artifact of measurement of coastal onlap versus offlap (Thorne and Watts, 1984), but subsequent generations of the EPR curve covering the past

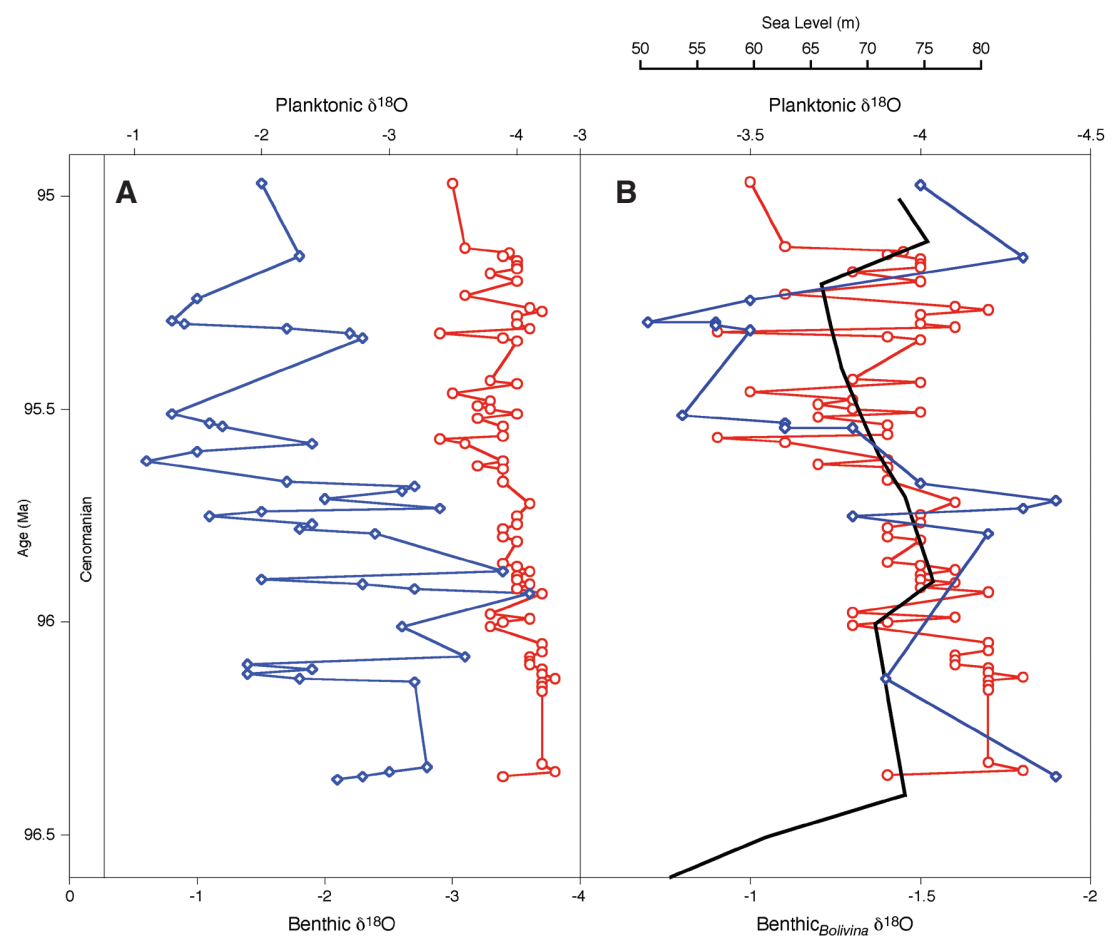

FIGURE 3 (A) Planktonic (red line) and benthic (blue line) $\delta^{18} \mathrm{O}$ record of Moriya et al. (2007) plotted with a full $4.5 \%$ range. Benthic foraminifera $\delta^{18} \mathrm{O}$ is based on the combined records of Bolivina anambra, Gavelinella spp., and Neobulimina spp. species. (B) Moriya et al.'s (2007) $\delta^{18} \mathrm{O}$ record of planktonic (red line) and benthic foraminifera Bolivina anambra (blue line) plotted on enlarged scales with $1.5 \%$ ranges; note different scales for benthic (bottom scale) and planktonic (top scale) values. Only values of Bolivina anambra greater than $-2 \%$ are included. Also shown is the sea-level record (black line) of Kominz et al. (in review) shifted in age by $\sim 0.2$ myr to maximize correlations. 


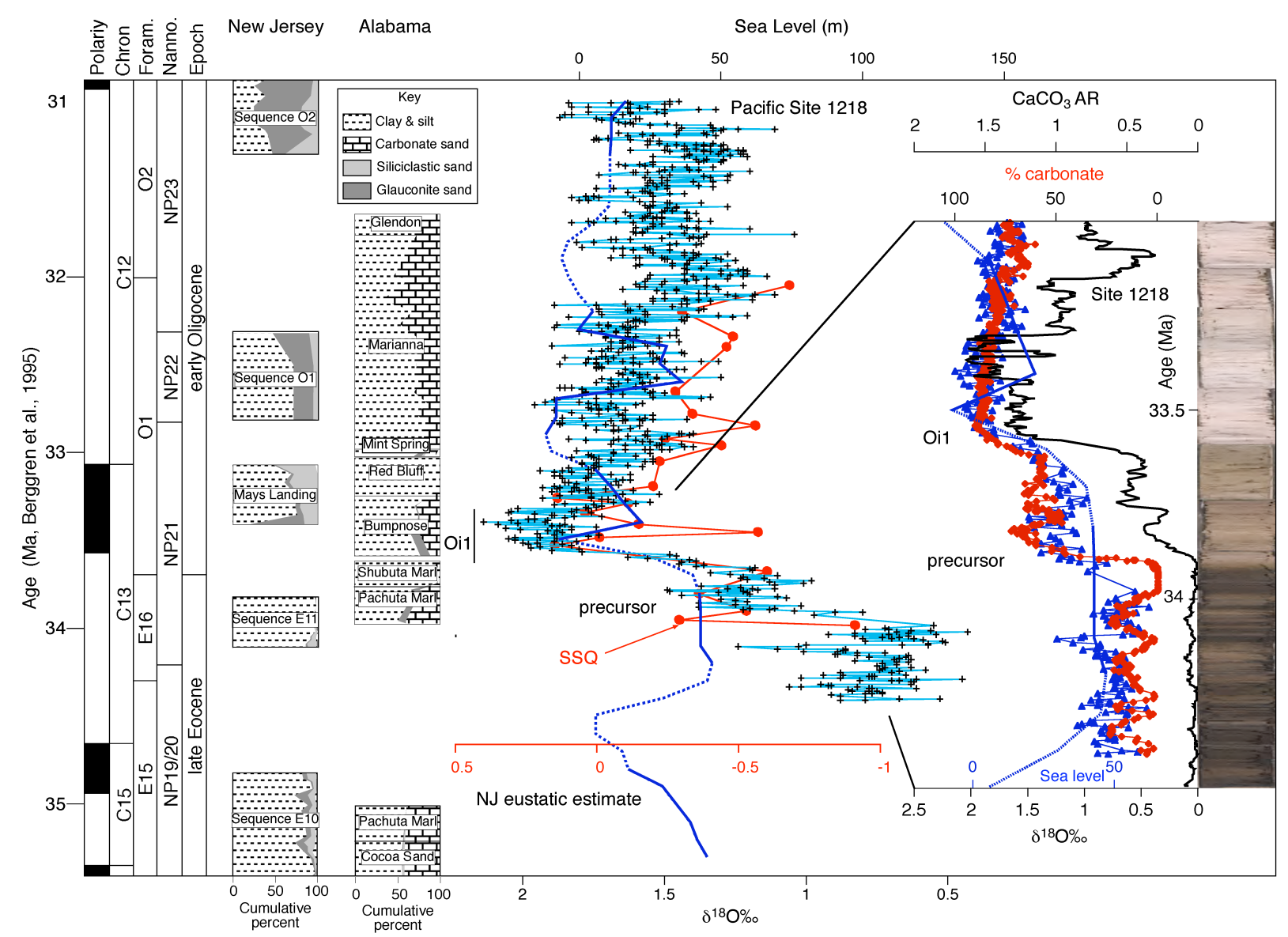

FIGURE 4 Comparison of continental margin records from New Jersey and Alabama (Miller et al., 2008), global sea-level estimates, and benthic foraminiferal $\delta^{18} \mathrm{O}$ records from deep Pacific ODP Site 1218 (Coxall et al., 2005) and St. Stephens Quarry, Alabama (Miller et al., 2004).

Shown at right is a blowup of ODP Site 1218 oxygen isotopes that includes carbonate percentage and mass accumulation rate (AR) data (Coxall et al., 2005) that shows two large drops associated with the precursor and Oi1 oxygen isotope increases that are reflected in the core photograph at right (light color $=$ carbonate rich; dark = carbonate poor).

200 myr still showed $100 \mathrm{~m}$ falls in much less than $1 \mathrm{myr}$ (Haq et al., 1987), including a mid-Oligocene fall of $\sim 160 \mathrm{~m}$. Though the EPR curves have been strongly criticized for their methodology and proprietary data (Christie-Blick et al., 1990; Miall, 1991), recently published sea-level estimates (Kominz et al., in review; Miller et al., 1998, 2005a) show that the timing of the EPR curves is largely correct. These recent estimates (discussed below) show that the EPR sealevel amplitudes are typically two to three times too high but still require tens of meters of change in much less than 1 myr.

Such rapid sea-level changes pose an enigma, because the only known mechanism for causing sea-level changes in excess of $10 \mathrm{~m}$ in less than $1 \mathrm{myr}$ is glacioeustasy (Pitman and Golovchenko, 1983). No other known mechanisms (steric effects, storage in lakes, deep-water changes, groundwater, or sea ice) can explain these changes (see Figure 1 in Miller et al., 2005a). Temperature changes can explain rapid sea-level changes such as the changes happening today, but the effect is small (i.e., a $10^{\circ} \mathrm{C}$ global warming would cause only a $10 \mathrm{~m}$ sea-level rise [Pitman and Golovchenko, 1983]). Changes in terrestrial storage in lakes and groundwater can only explain $5 \mathrm{~m}$ of sea-level change (Pitman and Golovchenko, 1983). Desiccating and refilling Mediterranean basins could explain very rapid $(<1 \mathrm{kyr})$ changes, but this effect is small $(\sim 10 \mathrm{~m})$ and it is impossible to explain the number of Late Cretaceous to early Eocene sea-level events with this mechanism (Pitman and Golovchenko, 1983). Thus only ice-volume changes can explain these large (tens of meters) sea-level changes, even in the supposedly ice-free world of the Late Cretaceous to Eocene.

Matthews and Poore (1980) first realized this enigma and Matthews (1984), based on sea-level records and his reinterpretation of the $\delta^{18} \mathrm{O}$ record, postulated that intermittent ice sheets occurred in the mid-Cretaceous through the Paleogene. Based on a comparison of continental margin and $\delta^{18} \mathrm{O}$ records, Miller et al. $(1987,1991)$ suggested that the growth and decay of continental ice sheets controlled 


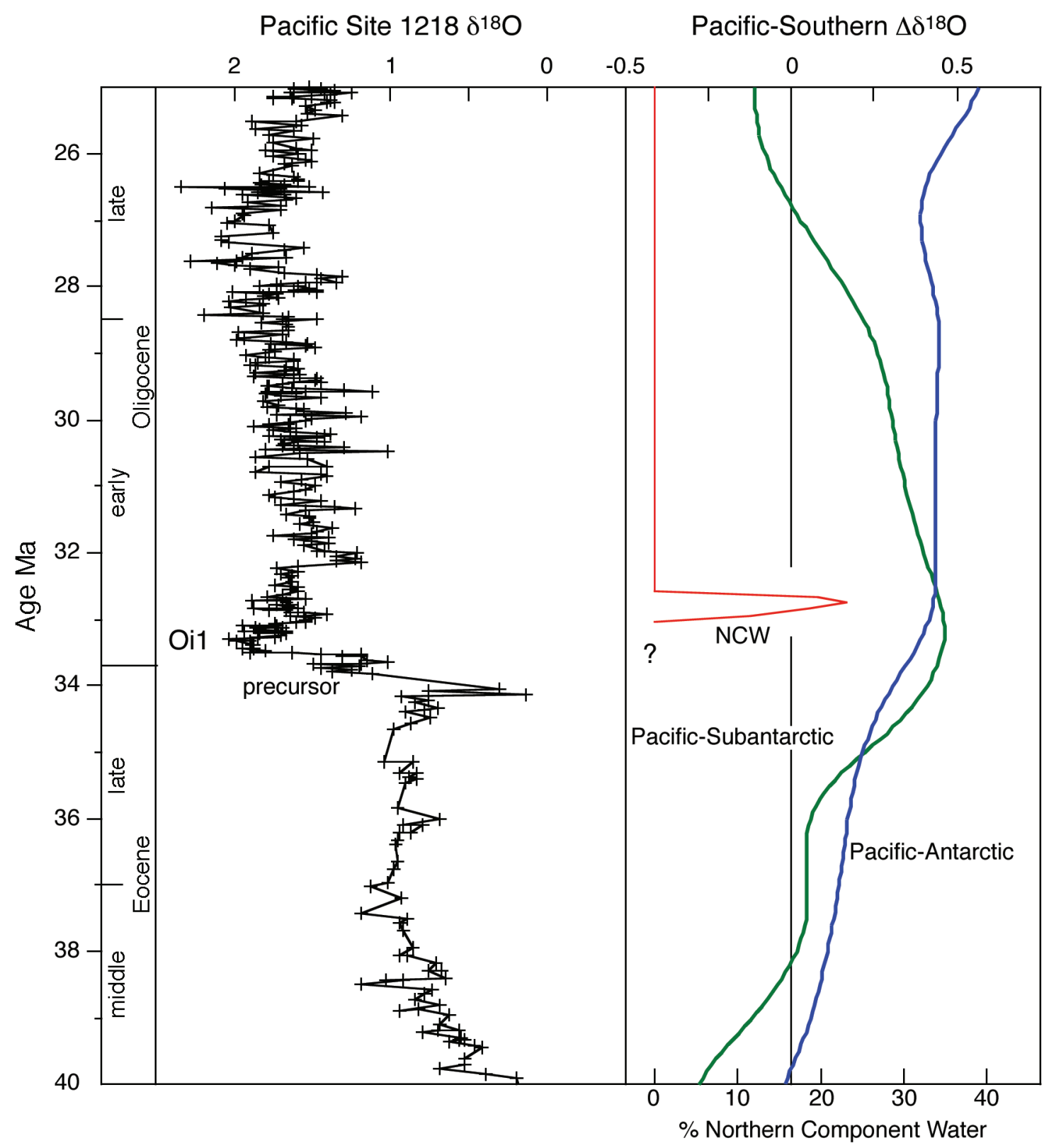

FIGURE 5 Comparison of benthic foraminiferal $\delta^{18} \mathrm{O}$ data from Pacific ODP Site 1218 (Coxall et al., 2005) with the percentage of northern component water (NCW) (Wright and Miller, 1996) and unpublished difference curve between a Pacific and southern ocean $\delta^{18} \mathrm{O}$ values. Values were interpolated to constant 0.1 myr intervals and smoothed with an 11-point Gaussian convolution filter using Igor Pro ${ }^{\circledR}$. Data were divided into Maud Rise sites closest to Antarctica and subantarctic sites. Timescale after Berggren et al. (1995).

sea-level changes in the Oligocene. Subsequent studies have confirmed the existence of Oligocene ice sheets (see Figure 1, and summaries of Miller et al., 1991; Zachos et al., 1994) and led to the suggestion that small- to medium-size ice sheets existed in the middle to late Eocene (Browning et al., 1996). Yet other than Matthews (1984) the concept of ice sheets during the interval of peak global warmth, the greenhouse world of the Late Cretaceous to Eocene, was ignored.
Stoll and Schrag (2000) examined mid-Cretaceous isotopic variations and revived Matthews's idea by postulating that continental ice sheets grew and decayed in this greenhouse world, and recent sea-level studies have supported their supposition (Kominz et al., in review; Miller et al., 2005a; Van Sickel et al., 2004).

Studies from the New Jersey coastal plain provided a eustatic estimate for the past $100 \mathrm{myr}$, using inverse models 
termed "backstripping" (Kominz et al., 1998, in review; Miller et al., 2005a; Van Sickel et al., 2004). Backstripping progressively removes the effects of sediment compaction and loading from observed basin subsidence (e.g., Kominz et al., 1998) and thermal-flexural subsidence is modeled by fitting exponential curves to the remaining observed subsidence. The difference between the best fit exponential curve and subsidence is a result of either eustatic change or any subsidence unrelated to thermal subsidence (Kominz et al., 1998). We have applied this technique to coreholes from the New Jersey and Delaware coastal plains by dating sequences (unconformity bounded units) with a \pm 0.5 myr or better resolution and developing a water depth history by integrating biofacies and lithofacies analysis. The similarity of records (six sites for the Cenozoic and four for the Cretaceous) (Miller et al., 2004) indicates that the effects of thermal subsidence, loading, and water-depth variations have been successfully removed. Backstripping, seismicity, seismic stratigraphic data, and distribution patterns of sediments all indicate minimal tectonic effects on the Late Cretaceous to Tertiary New Jersey coastal plain (Miller et al., 2004, 2005a), though some minor (10-30 m) differences between New Jersey and Delaware must be attributed to local subsidence or uplift (Browning et al., 2006).

The timing of sequences in New Jersey and other margins is similar, suggesting a global cause. There are few other backstripped records to test the New Jersey eustatic estimate against, though a Russian platform backstripped eustatic estimate (Sahagian et al., 1996) shows remarkably similar changes to New Jersey in the interval of overlap from 100 Ma to 90 Ma (Miller et al., 2003, 2005a; Van Sickel et al., 2004). In addition, comparison of the New Jersey record with northwest Europe (Ali and Hailwood, 1995; Hancock, 1993), the U.S. Gulf Coast (Mancini and Tew, 1995), the EPR synthesis (Haq et al., 1987), and long-term sea-level predictions from Milankovitch forcing (Matthews and Frohlich, 2002) suggests that Late Cretaceous to Eocene sea-level falls were rapid, synchronous, and global (see summary figures in Miller et al., 2004). Therefore, it is unlikely that the New Jersey eustatic estimate can be attributed to tectonics. The only mechanism than can explain the observed rates of sealevel change (in excess of $25 \mathrm{~m} / \mathrm{myr}$ ) is the growth and decay of continental ice sheets that caused glacioeustatic changes. Error bars for the sea-level falls are discussed in detail by Kominz et al. (in review). The greatest uncertainty is that the onshore sites mostly miss the lowstands and thus are minimal estimates of the eustatic falls. The Late Cretaceous to Eocene falls were typically $25 \mathrm{~m}$, with small events $(15 \mathrm{~m})$ near the detection level. The only exception was a large Campanian/ Maastrichtian boundary (ca. 71.5 Ma) sea-level fall of $40 \mathrm{~m}$. It should be noted that the New Jersey eustatic estimate must be considered a testable model. A true global sea-level curve must be derived from numerous margins, not just one; thus further studies are needed to validate this record.

Based on the New Jersey sea-level records, Miller et al.
(2003, 2004, 2005a,b) postulated the existence of ice sheets in the greenhouse world of the Late Cretaceous to Eocene. Miller et al. (2005b) presented a new view of Earth's cryospheric evolution that reconciled warm, largely ice-free poles with cold periods that resulted in glacioeustatic lowerings. Their view was developed from work by DeConto and Pollard (2003a,b) who used a coupled global climate and icesheet model that accounts for bedrock loading, lapse rate effects of topography, surface mass balance, basal melting, and ice flow and computes both the sea level and $\delta^{18} \mathrm{O}$ effects of ice growth. The DeConto and Pollard (2003a,b) model used declining atmospheric $\mathrm{CO}_{2}$ values of $\sim 3$ to 2 times present day, similar to empirical estimates for declining $\mathrm{CO}_{2}$ from the Eocene to Oligocene (Pagani et al., 2005). These model runs were used to estimate the size and geographic distribution of ice sheets (Figure 2) for Oligocene continental configurations, though the modeling results are applicable to the older record as long as Antarctica was a polar continent (i.e., for the entire interval considered here).

We estimate Antarctic ice volume using the New Jersey sea-level record (Figure 2). The typical 15-30 m greenhouse eustatic falls correspond to growth of ice volumes of $8-12 \times 10^{6} \mathrm{~km}^{3}$ using a $0.1 \%$ o/10 m calibration of sea level and ice volume (DeConto and Pollard, 2003a,b). The exception is the large Campanian/Maastrichtian boundary fall of $40 \mathrm{~m}$ that suggests growth of an ice sheet of $17 \times 10^{6} \mathrm{~km}^{3}$. As illustrated in Figure 2, these ice sheets did not reach the Antarctic coast. This together with the fact that this ice sheet probably existed for relatively short periods (see below) reconciles ice with coastal warmth in Antarctica. Though the temporal coverage is limited, there is ample evidence that Antarctic coastal climates were quite warm during much of the Late Cretaceous to Eocene (e.g., Askin, 1989; Francis and Poole, 2002); deep waters were relatively warm also (e.g., early Maastrichtian paleotemperatures of $\sim 10^{\circ} \mathrm{C}$ at $1500 \mathrm{~m}$ paleodepth on the Maud Rise) (Barrera and Huber, 1990). Yet these coastal and offshore studies do not address regions of ice sheet nucleation predicted for the continental interiors (Figure 2) (DeConto and Pollard, 2003a,b).

These ice sheets were ephemeral and for the most part Antarctica lacked ice sheets during the greenhouse world except for these cool or cold periods, called "cool snaps" by Royer et al. (2004). It is not possible to say how long these cool or cold intervals lasted. Matthews and Frohlich (2002) computed an estimated Cretaceous sea-level and icevolume curve based on Milankovitch forcing, and minima in this curve appear to correlate with sequence boundaries in New Jersey (Miller et al., 2005b). The dominant beats in the predicted curve are the ca. 2.4 myr and 405 kyr very long and long eccentricity cycles and the 1.2 myr tilt cycle. Yet these longer-term modulations predict that shorter-term periods (tilt and precession) must have been operative and it seems likely that the cool intervals only lasted during minima in insolation on the precession and tilt periods. Studies of myr-scale sea-level events in the Oligocene suggest that peak 
cold intervals lasted only 2-3 tilt (41 kyr) cycles (Coxall et al., 2005; Zachos et al., 1996). Thus we speculate that ice sheets existed only for brief intervals ( $100 \mathrm{kyr}$ for a typical 2.4 myr cycle) during the greenhouse.

We illustrated Antarctic cryospheric evolution using maps derived from the models of DeConto and Pollard (2003b). These maps show areas and thicknesses computed from the models, which also compute the equivalent water volume and sea level. We correlate each map and its attendant sea-level fall to equivalent sea-level falls estimated in New Jersey (e.g., the map for a $40 \mathrm{~m}$ fall is aligned with the $40 \mathrm{~m} 71.5 \mathrm{Ma}$ fall) (Figure 2). For periods of small ( $\sim 15$ $\mathrm{m})$ sea-level falls that typified most of the Late Cretaceous and early Eocene, models indicate that small isolated ice caps would have formed in the highest elevation of Dronning Maud Land, the Gamburtsev Plateau, and the Transantarctic Mountains (Figure 2) under high $\mathrm{CO}_{2}$ conditions. For periods with moderate sea-level falls $(25 \mathrm{~m})$ that were typical of the larger events in greenhouse intervals (e.g., the mid-Turonian and mid-Cenomanian), a small ice-sheet threshold was reached owing to height and mass balance feedback; the three ice sheets (Dronning Maud Land, the Gamburtsev Plateau, and the Transantarctic Mountain) continued to grow but not coalesce, and were isolated from the coast. With a $40 \mathrm{~m}$ sea-level lowering, ice caps would have begun to coalesce (Figure 2); this configuration would have been achieved only during the largest of the greenhouse sea-level falls (e.g., the 71.5 Ma Campanian/Maastrichtian event). With sea-level falls of over $50 \mathrm{~m}$, the three ice-sheet nodes would have united (Figure 2); this configuration would not have been achieved until $\mathrm{CO}_{2}$ fell below a critical threshold (estimated at 2.8 times preanthropogenic levels) (DeConto and Pollard, 2003a,b) in the earliest Oligocene (33.55 Ma).

The elevation of Antarctica in the greenhouse world is an important unknown. The models of DeConto and Pollard (2003a) account for changes in elevation due to isostasy and mountain building and are appropriate for Oligocene and later Eocene configurations. However, the elevation of the continent may have been lower in the earliest Eocene and older. Uplift of the Transantarctic Mountains may have begun in the Cretaceous (Fitzgerald, 2002), though it is also possible that uplift did not begin until the Eocene (ten Brink et al., 1997). We concede that it may have been more difficult to nucleate ice sheets on a lower continent but maintain that the elevational history of Antarctica is poorly known.

The scenario for Late Cretaceous to Cenozoic ice-sheet history (Figure 2) is partly testable with $\delta^{18} \mathrm{O}$ data because each sea-level event should be associated with a $\delta^{18} \mathrm{O}$ increase due to ice growth. This prediction has been verified for the Oligocene to middle Miocene (Miller et al., 1996, 1998) and extended back to the middle to late Eocene, where sea-level changes are coupled with $\delta^{18} \mathrm{O}$ increases (Browning et al., 1996), suggesting glacioeustatic control. Tripati et al. (2005) also used stable isotopic data to argue for middle and late Eocene ice sheets. Cretaceous to early Eocene $\delta^{18} \mathrm{O}$ data are sparse because of poor core recovery and diagenesis (i.e., isotopic studies of sections with $>400 \mathrm{~m}$ burial are suspect) (1987), but some comparisons can be made. The large Campanian/Maastrichtian boundary sea-level fall is associated with a major $\delta^{18} \mathrm{O}$ increase in both planktonic and benthic foraminifera (Miller et al., 1999, using data of Barrera and Savin, 1999; and Huber et al., 2002). Also, large (>0.75\%o) mid-Cenomanian (ca. $96 \mathrm{Ma}$ ) and mid-Turonian (ca. 92-93 $\mathrm{Ma}$ ) benthic foraminiferal $\delta^{18} \mathrm{O}$ increases reported from western North Atlantic ODP Site 1050 (Huber et al., 2002) correlate with major sea-level falls in New Jersey. These large $\delta^{18} \mathrm{O}$ increases at $92-93 \mathrm{Ma}$ and $96 \mathrm{Ma}$ cannot be entirely attributed to ice-volume changes because this would require ice sheets larger than those of modern times, and in fact much of the $\delta^{18} \mathrm{O}$ signal must be attributed to deep-sea (hence inferred high-latitude; see below) temperature change. Miller et al. (2005b) estimated that about two-thirds of the $\delta^{18} \mathrm{O}$ signal was attributable to temperature, suggesting about $0.25 \%$ was due to a change in $\delta^{18} \mathrm{O}_{\text {seawater }}$, corresponding to a sea-level change of $\sim 25 \mathrm{~m}$ and growth of about one-third of the Antarctic ice sheet.

A recent study has challenged correlations of sea-level falls and $\delta^{18} \mathrm{O}$ increases for the Cenomanian. Moriya et al. (2007) tested evidence for Cenomanian glacioeustasy by generating high-resolution (26 kyr sampling) benthic and planktonic $\delta^{18} \mathrm{O}$ records from ODP Site 1258 on the Demerara Rise (western tropical Atlantic Ocean). They concluded that there was no support for Cretaceous glaciation and called into question evidence for greenhouse ice sheets. We replotted their data (Figure 3) and make the following observations:

1. Benthic foraminiferal $\delta^{18} \mathrm{O}$ values from the Demerara Rise (Moriya et al., 2007) show very large amplitudes (up to $3 \%$ ) that would require deep-water temperature changes of $13^{\circ} \mathrm{C}$ in a few $100 \mathrm{kyr}$ (Figure 3). The extremely low benthic $\delta^{18} \mathrm{O}$ values (less than $-4 \%$, mean value of $-1.8 \%$ ) correspond to maximum and average deep-water temperatures of $30^{\circ} \mathrm{C}$ and $19.5^{\circ} \mathrm{C}$, respectively (assuming an ice-free $\delta^{18} \mathrm{O}_{\text {seawater }}$ value of -1.2\%o) (Moriya et al., 2007). Considering that the lowest benthic foraminiferal $\delta^{18} \mathrm{O}$ values for the Cenomanian at western North Atlantic ODP Site 1050 (Figure 2) (Huber et al., 2002) are $-1.4 \%$ o to $-1.6 \%$, corresponding to deep-water temperatures of $18-19^{\circ} \mathrm{C}$, we suggest that Moriya et al.'s (2007) benthic foraminiferal records are overprinted by diagenesis, very large local $\delta^{18} \mathrm{O}_{\text {seawater }}$ effects, or by analysis of multiple species with very large vital effects. Their $\delta^{18} \mathrm{O}$ values on the genus Neobulimina particularly show considerable variations, with many values close to those of planktonic foraminifera. We culled their benthic foraminiferal $\delta^{18} \mathrm{O}$, accepting only Bolivina data and rejecting all values lower than $-2 \%$ as physically unrealistic; the resulting dataset shows a similar pattern to the planktonic $\delta^{18} \mathrm{O}$ record (Figure $\left.3 b\right)$. 
2. Though Moriya et al. (2007) claimed minimal change in planktonic foraminiferal $\delta^{18} \mathrm{O}$ values, this is largely an artifact of the scale of $5 \%$ on which the data were plotted (e.g., Figure 3a). Plotting planktonic foraminiferal $\delta^{18} \mathrm{O}$ values with a $1.5 \%$ o scale (Figure $3 \mathrm{~b}$ ) show that values increase by $\sim 0.5-0.6 \%$ in the mid-Cenomanian $(\sim 95.5 \mathrm{Ma})$ at precisely the same time as the sea-level fall delineated in New Jersey (Figure 3).

3. As noted by Miller et al. (2005a) and Moriya et al. (2007), $\delta^{18} \mathrm{O}_{\text {seawater }}$ effects for these greenhouse ice sheets would have been small $(\sim 0.2-0.3 \%$ ) , but this is detectable within measurement error. While we have observed and would reasonably expect cooler deep-water temperatures associated with these greenhouse ice-growth events (e.g., two-thirds of the Campanian/Maastrichtian fall must be due to cooling), there is no reason to require proportional coupling of cooling and ice volume as suggested by Moriya et al. (2007). In fact, we suspect that one reason that early Eocene ice-volume events have proven to be so elusive is that there was little change in deep-water temperature and the ice-volume signal is quite small $(0.2-0.3 \%$ o).

4. Thus the Demerera Rise isotope data are consistent with (rather than disprove) the idea that there was a seawater $\delta^{18} \mathrm{O}$ change on the order of $\sim 0.2-0.3 \%$ associated with the mid-Cenomanian event.

We conclude that sea-level records indicate that smallto medium-size $\left(10-15 \times 10^{6} \mathrm{~km}^{3}\right)$, ephemeral (lasting a few tilt cycles based on analogy with high-resolution Oligocene studies of Zachos et al., 1994) ice sheets occurred during the greenhouse world of the Late Cretaceous to middle Eocene. However, an Antarctic record of these glaciations exists only from the middle Eocene (Figure 1).

\section{THE BIG CHILL INTO THE ICEHOUSE: THE EOCENE-OLIGOCENE TRANSITION}

Following peak warmth in the early Eocene (ca. $50 \mathrm{Ma}$ ), benthic foraminiferal deep-water and by extension high-latitude surface waters cooled across the early to middle Eocene boundary (ca. 48-49 Ma) and in the late middle Eocene (ca. 44-41 Ma) (Figure 2). The sea-level record shows development of progressively larger ice sheets in the middle to late Eocene (Figure 2). The Eocene-Oligocene transition culminated with the largest $\delta^{18} \mathrm{O}$ increase of the past $50 \mathrm{myr}$, the earliest Oligocene Oi1 $\delta^{18} \mathrm{O}$ maximum (33.55 Ma).

Antarctica entered the icehouse in the earliest Oligocene (33.55 Ma). There is widespread evidence for large ice sheets (IRD and grounded diamictons [Figure 1]) and we suggest that Antarctica was nearly fully glaciated. A eustatic fall of $55-70 \mathrm{~m}$ occurred at $33.55 \mathrm{Ma}$ in association with the $\delta^{18} \mathrm{O}$ increase. This corresponds to an Antarctic ice sheet that was 80-100 percent of the size of the present-day East Antarctic ice sheet (today a sea-level equivalent of $\sim 63 \mathrm{~m}$ is stored in East Antarctica and 5-7 m in West Antarctica; see discus- sion below). If fully compensated by isostasy, this $55-70 \mathrm{~m}$ represents $\sim 82-105 \mathrm{~m}$ of change in water volume or apparent sea level (Pekar et al., 2002), which would correspond with 115-150 percent of the modern Antarctic ice sheet or 100-130 percent of the entire modern ice inventory.

These large ice estimates require storage of ice outside East Antarctica. Though earlier studies assumed that the West Antarctic ice sheet did not develop until the later Miocene (Kennett, 1977), recent studies (Ivany et al., 2006) suggest that glacial ice extended to sea level in this region by the earliest Oligocene; these were not just mountain glaciers. This is supported by seismic stratigraphic evidence summarized by Cooper et al. (forthcoming) for glacial influences in both East and West Antarctica beginning in the Oligocene.

These sea-level changes suggest at least moderate glaciation in the Northern Hemisphere in the earliest Oligocene. Today the Greenland ice sheet is composed of $6.5 \mathrm{~m}$ (Williams and Ferrigno, 1995) of sea-level equivalent. Tripati et al. (2005) have argued for very large (tens of meters) NHISs in the earliest Oligocene. They attribute the entire $\delta^{18} \mathrm{O}$ increase observed in the deep Pacific to growth of ice sheets because $\mathrm{Mg} / \mathrm{Ca}$ data associated with the Oi1 $\delta^{18} \mathrm{O}$ increase. $\mathrm{Mg} / \mathrm{Ca}$ data for Oi1 time indicate a $2{ }^{\circ} \mathrm{C}$ warming that is an artifact of carbonate undersaturation in the deep sea (Lear and Rosenthal, 2006). However, though there is evidence for localized Northern Hemisphere glaciation in the Paleogene (Eldrett et al., 2007; Moran et al., 2006), the first appearance of IRD in the North Atlantic outside the Norwegian-Greenland Sea did not occur until 2.6 Ma (Shackleton et al., 1984). The Eocene IRD evidence presented by Eldrett et al. (2007) and Moran et al. (2006) is compelling but limited to the high-latitude NorwegianGreenland Sea and Arctic and does not indicate widespread Northern Hemisphere glaciation. We thus doubt the presence of very large (tens of meters equivalent) ice sheets in the Northern Hemisphere prior to 2.6 Ma.

The suggestion that the Antarctic ice sheet was as large if not larger than today needs to be reconciled with paleobotanical data that suggest that ice-free refugia are needed for the Oligocene (e.g., Francis and Poole, 2002). Drilling in the Weddell Sea highlights this enigma; lowermost Oligocene grounded diamictons are overlain by strata containing Nothofagus leaves (Kennett and Barker, 1990). This is consistent with our scenario based on sea-level and stable isotopic studies (Coxall et al., 2005; Zachos et al., 1996) that earliest Oligocene ice sheets formed rapidly $(<<1$ myr) in a series of Milankovitch tilt-driven (41 kyr) increases that lasted for a few hundred kyr, and then almost completely collapsed again, only to reform again at Oila time (ca. $33 \mathrm{Ma}$ ), but it leaves open the question of where these refugia were located during times of maximum glaciation. Under true icehouse conditions that began in the earliest Oligocene, the ice sheet reached the coastline (Figure 2), which limited its further growth. The sea-level estimates suggest a minimum drop of $55 \mathrm{~m}$, which is illustrated by calving along much of 
the coastline except Wilkes Land (Figure 2); however, our upper limit eustatic lowering of 70-105 m would require ice volumes exceeding modern, and thus reaching the coast along much of the margin.

Using data of Miller et al. (2008), we present a detailed view of the climate changes that spanned the EoceneOligocene boundary (Figure 4). The Eocene-Oligocene transition is associated with a long-term $\left(10^{7} \mathrm{yr}\right.$ scale $) \mathrm{CO}_{2}$ drawdown (Pagani et al., 2005) and related temperature change that triggered a precursor $\delta^{18} \mathrm{O}$ increase at $33.8 \mathrm{Ma}$ of $\sim 0.5 \%$ o identified at Pacific ODP Site 1218 (Coxall et al., 2005) and shelf site at St. Stephens Quarry, Alabama (Miller et al., 2008), followed by a $1.0 \% \circ \delta^{18} \mathrm{O}$ increase at $33.55 \mathrm{Ma}$ (= Oi1, earliest Oligocene). This is consistent with models that predict climate response of at least two nonlinear jumps associated with the transition (DeConto and Pollard, 2003b). The precursor increase is not associated with an observable change in sea level (i.e., a change greater than 15-20 m), suggesting that it was caused by a $2^{\circ} \mathrm{C}$ cooling, not ice-sheet growth (Miller et al., 2008). Global sea level dropped by $\sim 55-82 \mathrm{~m}$ at $33.55 \mathrm{Ma}$, indicating that the deep-sea $\delta^{18} \mathrm{O}$ increase was due to transfer of the water from the oceans to the Antarctic ice sheet, which was 80-130 percent of the modern size, as discussed above. The amount of cooling associated with Oi1 is still uncertain. Using the $55 \mathrm{~m}$ fall and a calibration of $0.1 \% / 10$ $\mathrm{m}$ (DeConto and Pollard, 2003b) suggests that deep-water temperatures dropped $2^{\circ} \mathrm{C}$; using the higher sea-level fall (82 $\mathrm{m}$ ) suggests only $1^{\circ} \mathrm{C}$ of cooling.

The Antarctic ice sheet reached the coastline for the first time in the earliest Oligocene (Figure 2) and this large ice sheet became a driver of, not just a response to, climate change. The earliest Oligocene was characterized by increased latitudinal thermal gradients (Kennett, 1977). This increase caused: (1) enhanced wind intensities and a spinning up of the oceans, resulting in increased upwelling (Suko, 2006) and increased thermohaline circulation, with transient erosional pulses of North Atlantic deep water (Miller and Tucholke, 1983; Wright and Miller, 1996) and AABW (Kennett, 1977; Wright and Miller, 1996); (2) a major drop in the CCD as the deep oceans cooled, became better ventilated, and had reduced residence time and acidity (Figure 4) (Coxall et al., 2005; van Andel, 1975); and (3) a large increase in diatom diversity due to intensified latitudinal thermal gradients and upwelling (Falkowski et al., 2004; Finkel et al., 2005; Pak and Miller, 1992).

Seismic stratigraphy and mapping of hiatuses indicate a major strengthening of thermohaline circulation in the Oligocene. The Antarctic has generally been a source of deep water to the oceans (analogous to AABW) throughout much of the later Cretaceous and the Cenozoic (Pak and Miller, 1992; Mountain and Miller, 1992). The Eocene-Oligocene boundary saw intensification of AABW. Kennett (1977) and Wright and Miller (1996) showed that numerous hiatuses in the southern ocean are attributable to erosional pulses of
$\mathrm{AABW}$, with a large one at the Eocene-Oligocene boundary. In the North Atlantic a major erosional pulse was associated with reflectors R4 (Miller and Tucholke, 1983) and $\mathrm{A}^{\mathrm{u}}$ (Tucholke and Mountain, 1979), both of which date to near the Eocene-Oligocene boundary (Mountain and Miller, 1992). Northern Hemisphere high latitudes cooled concomitantly with polar cooling in the Southern Hemisphere, making the North Atlantic a viable source region for deep water (albeit briefly) in the earliest Oligocene.

Stable isotope reconstructions are generally consistent with the scenario derived from mapping of hiatuses and seismic disconformities. Carbon isotopic reconstructions of the Oligocene show low vertical and interbasinal differences (Diester-Haass and Zachos, 2003; Miller and Fairbanks, 1985; Salamy and Zachos, 1999; Wade and Pälike, 2004), limiting the use of this proxy for reconstructing deep-water changes. We attribute these low gradients to a general decrease in export production; although the spin-up of the oceans increased export productivity in eutrophic areas (Moore et al., 2004), available nutrients limited general export production, which was remarkably low in oligotrophic areas (Miller and Katz, 1987). Despite the low Oligocene $\delta^{13} \mathrm{C}$ sensitivity (and the resulting flat line on Figure 5), $\delta^{13} \mathrm{C}$ records indicate that there was a short early Oligocene interval (ca. 33-32 Ma) with high Atlantic-Pacific $\delta^{13} \mathrm{C}$ gradients (Miller, 1992); Wright and Miller (1996) quantified the percentage of northern component water using interbasinal $\delta^{13} \mathrm{C}$ gradients (Figure 5).

Oxygen isotopic records indicate that the Antarctic was the source of water with high $\delta^{18} \mathrm{O}$ values in the late middle to late Eocene (Figure 5). ODP Site 689 on the Maud Rise (1800 m paleodepth) (Kennett and Stott, 1990; Thomas, 1990) records very high $\delta^{18} \mathrm{O}$ values beginning with the late middle Eocene cooling and staying high through the Oligocene (Figure 5). This "cold spigot" indicates that AABW had a strong cold influence close to the continent, but this influence was reduced by mixing away from the proximal southern ocean (Miller, 1992). Subantarctic $\delta^{18} \mathrm{O}$ records show that the cold water mass did not strongly influence regions further from the continent until the end of the Eocene (Figure 5). Very high subantarctic $\delta^{18} \mathrm{O}$ values during the Eocene-Oligocene transition suggest a pulse of AABW that peaked with the Oil glaciation (Figure 5), consistent with the erosional record (Kennett, 1977; Wright and Miller, 1996). This increase in thermohaline circulation is coincident with the drop in the calcite compensation depth.

The drop in the CCD was caused by increased thermohaline circulation that caused a decrease in oceanic residence time and a decrease in deep-ocean acidity. Coxall et al. (2005) showed that the CCD drop occurred in two steps associated with the precursor and $\delta^{18} \mathrm{O}$ increases (Figure $4)$; the drop in percentage of carbonate at the precursor event was as large or larger than at Oi1 time (Figure 5), but accumulation rate data indicate that the latter event was more significant. The cause of the drop in the CCD has been 
debatable. Any deepening of the CCD must be attributed to one of the following:

1. An increase in deep-basin carbonate deposition at the expense of shallow carbonates (shelf-basin fractionation, as invoked by Coxall et al., 2005) for this drop. We argue that shelf-basin fractionation cannot be invoked to explain the CCD drop associated with the precursor $\delta^{18} \mathrm{O}$ increase, because there is little or no sea-level fall during the precursor; in addition, they note that the amount of eustatic fall $(55-82 \mathrm{~m})$ associated with the $33.55 \mathrm{Ma}$ Oi1 $\delta^{18} \mathrm{O}$ increase is too small to account for the large deepening of the CCD.

2. A global intensification of carbonate export to the deep sea caused by increased continental input to the oceans. Weathering rates increased in the earliest Oligocene (Robert and Kennett, 1997) and may have contributed to a global increase in carbonate production. However, global Oligocene sedimentation rates were low (Thunell and Corliss, 1986), and it is doubtful that input changes could explain the CCD drop. Rea and Lyle (2005) argued that the CCD drop could not be entirely due to shelf-basin shift and suggested that a sudden increase in weathering and erosion rates is unlikely to account for the change, thus implicating changes in deep-sea preservation.

3. A large deep-water cooling. Cooling may have contributed to the CCD falls, but the minor amount of cooling at Oi1 time $\left(1-2^{\circ} \mathrm{C}\right.$ as discussed above $)$ cannot fully explain this drop.

4. A decrease of deep-ocean residence time. The links among deep-sea temperature, an increase in thermohaline circulation, and the drop in the CCD (Figure 4) are manifested as to the cause: a decrease in ocean acidity due to decreased residence time.

Following the earliest Oligocene event, Oligocene to middle Miocene ice sheets vacillated from near modern volumes to nearly fully deglaciated at times. This was a transitional period, with a wet-based Antarctic ice sheet (Marchant et al., 1993). Atmospheric $\mathrm{CO}_{2}$ was at near-preanthropogenic levels (Pagani et al., 2005). A 1.2-1.5\% middle Miocene (ca. 14.8-12 Ma) $\delta^{18} \mathrm{O}$ increase is associated with a major sea-level fall, which this event most likely represents the development of polar desert conditions with a permanent ice cap in Antarctica (Shackleton and Kennett, 1975) (Figure 2). There has been intense debate about whether this ice cap was indeed permanent, or whether it in fact disintegrated in the early Pliocene (Kennett and Hodell, 1996). We note that the amplitude of the myr-scale variability in both $\delta^{18} \mathrm{O}$ and sealevel records appears to be lower after the middle Miocene event (Figure 2), suggesting relative stability.

\section{QUO VADIM?}

We present a review of Antarctic glacial history as interpreted from sea-level and oxygen isotopic records, updating and integrating previous reviews of sea-level change (Miller et al., 2005a), greenhouse ice sheets (Miller et al., 2005b), new data from the Eocene-Oligocene transition (Miller et al., 2008), and deep-sea circulation changes (Wright and Miller, 1996). The sea-level record was recently updated (Figure 2) by Kominz et al. (in review) who presented a thorough error analysis. We can make certain statements about sea-level changes:

1. Very high-amplitude, myr-scale sea-level changes (up to $160 \mathrm{~m}$ ) of EPR are not supported.

2. Our sea-level record (Figure 2) is derived from studies of only one margin, except for the interval from $90 \mathrm{Ma}$ to $100 \mathrm{Ma}$, which is corroborated by the Russian Platform (Sahagian et al., 1996). A true global sea-level curve must be derived from numerous margins and thus the curve presented must be considered a testable model. Further studies are needed to validate this record.

3. Our best estimate of greenhouse sea-level amplitudes are $15-25 \mathrm{~m}$ on the myr scale, except for the ca. 71.5 Ma event, which was over $40 \mathrm{~m}$. Icehouse amplitudes are as high as $55-70 \mathrm{~m}$. We do not capture most lowstands in our sea-level record, and these estimates are minima.

4. The New Jersey estimates are eustatic, having been corrected for the effects of loading. To estimate the actual volume of ice equivalent requires the making of assumptions about isostatic effects due to water loading. As noted by Pekar et al. (2002) a eustatic change of $55 \mathrm{~m}$ would require a change in water volume of $82 \mathrm{~m}$, assuming full compensation. Similarly, in the younger record the change from $18 \mathrm{ka}$ to present of 120 m measured in Barbados (Fairbanks, 1989) would have caused an $80 \mathrm{~m}$ eustatic change, assuming full compensation. On the myr scale considered here, compensation was likely partially achieved (Peltier, 1997) and thus the actual changes in water volume would have been higher than eustatic estimates.

5. The link of sea-level falls and $\delta^{18} \mathrm{O}$ increases has been documented for numerous icehouse increases. This relationship is expected because glacioeustasy is expected to drive sea-level change during this time. Further studies evaluating the link of $\delta^{18} \mathrm{O}$ and sea level in the greenhouse are needed, though preliminary comparisons are intriguing. It must be remembered that we predict small $(\sim 0.2-0.3 \%$ o $)$ $\delta^{18} \mathrm{O}_{\text {seawater }}$ changes for greenhouse ice-volume changes.

Oxygen isotopic variations can be used to place constraints on Antarctic ice history. The firmest constraint is that ice sheets are required when benthic foraminiferal $\delta^{18} \mathrm{O}$ values exceed $1.8 \%$ in Cibicidoides (Miller and Fairbanks, 1983; Miller et al., 1991). For the greenhouse world, $\delta^{18} \mathrm{O}$ values suggest largely warm high latitudes, at least near the coast, where deep waters form. However, we need to be careful in assuming that warm coastal Antarctic temperatures indicate a continent devoid of ice sheets for the period 100-33.55 Ma. As models illustrate (DeConto and Pollard, 
2003a,b), the Antarctic continent may have been remarkably diverse during the greenhouse with unglaciated coastal regions and small- to moderate-size ice sheets in the interior. Though much of the evidence may have been destroyed or buried by the modern ice sheet, the challenge now is to seek evidence for these greenhouse ice sheets. Intense study of the Antarctic continent has demonstrated the importance of ice sheets on sedimentation over the past 33 myr and provided hints of cold conditions even in the Eocene (Figure 1). Comparison with the Arctic is illustrative. Until the most sensitive area of the Arctic was drilled by IODP (Moran et al., 2006), it was assumed that the Arctic was not glaciated until the later Cenozoic and bipolar glaciation was a relatively recent event. In contrast, sampling on the Lomonsov Ridge has extended the glacial record of the Arctic back to $\sim 46 \mathrm{Ma}$ (Moran et al., 2006), and we predict that future studies of Antarctica will result in extension of small- to medium-size ice sheets back into the Late Cretaceous.

\section{ACKNOWLEDGMENTS}

We thank J. P. Kennett and S. F. Pekar for reviews and A. Cooper for suggestions. The ideas presented here were developed with help from previous reviews of sea-level change (Kominz et al., in review; Miller et al., 2005a), greenhouse ice sheets (Miller et al., 2005a), the Eocene-Oligocene transition (Miller et al., 2008), and deep-sea circulation changes (Wright and Miller, 1996); we thank co-authors of those papers, who are not listed here, for helping to develop our views of Antarctic glacial history. Supported by National Science Foundation grants EAR06-06693 (Miller) and OCE0623256 (Katz, Miller, Wade, and Wright).

\section{REFERENCES}

Ali, J., and E. A. Hailwood. 1995. Magnetostratigraphy of upper Paleocene through lower middle Eocene strata of northwest Europe. In Geochronology, Time Scales and Global Stratigraphic Correlation, eds. W. A. Berggren, D. V. Kent, M.-P. Aubry, and J. Hardenbol, pp. 275-279. Special Publication. Tulsa, OK: Society for Sedimentary Geology.

Askin, R. A. 1989. Endemism and heterochroneity in the Late Cretaceous (Campanian) to Paleocene palynofloras of Seymour Island, Antarctica: Implications for origins, dispersal and palaeoclimates of southern floras. In Origins and Evolution of the Antarctic Biota, ed. J. A. Crame, pp. 107-119. Special Publication. Geological Society of London.

Barrera, E., and B. T. Huber. 1990. Evolution of Antarctic waters during the Maestrichtian: foraminifer oxygen and carbon isotope ratios, ODP Leg 113. In Proceedings of the Ocean Drilling Program, Scientific Results, vol. 113, eds. P. F. Barker and J. P. Kennett, pp. 813-823. College Station, TX: Ocean Drilling Program.

Barrera, E., and S. M. Savin. 1999. Evolution of late Campanian-Maastrichtian marine climates and oceans. Geological Society of America Special Papers 332:245-282.

Barrett, P. J. 2007. Cenozoic climate and sea level history from glacimarine strata off the Victoria Land coast, Cape Roberts Project, Antarctica. In Glacial Processes and Products, eds. M. J. Hambrey, P. Christoffersen, N. F. Glasser, and B. Hubbart. International Association of Sedimentologists Special Publication 39:259-287.
Barrett, P. J., D. P. Elston, D. M. Harwood, B. C. McKelvey, and P.-N. Webb. 1987. Mid-Cenozoic record of glaciation and sea level change on the margin of the Victoria Land Basin, Antarctica. Geology 15:634-637.

Barron, J. A., and B. Larsen. 1989. Proceedings of the Ocean Drilling Program, Initial Reports, vol. 119. College Station, TX: Ocean Drilling Program.

Berggren, W. A., D. V. Kent, C. C. Swisher, and M.-P. Aubry. 1995. A revised Cenozoic geochronology and chronostratigraphy. In Geochronology, Time Scales and Global Stratigraphic Correlations: A Unified Temporal Framework for an Historical Geology, eds. W. A. Berggren, D. V. Kent, M.-P. Aubry, and J. Hardenbol, pp. 129-212. Special Publication. Tulsa, OK: Society for Sedimentary Geology.

Birkenmajer, K. 1991. Tertiary glaciation in the South Shetland Islands, West Antarctica: Evaluation of data. In Geological Evolution of Antarctica, eds. M. R. A. Thomson, J. A. Crame, and J. W. Thomson, pp. 629-632. Cambridge: Cambridge University Press.

Birkenmajer, K., A. Gazdzicki, K. P. Krajewski, A. Przybycin, A. Solecki, A. Tatur, and H. I. Oon. 2005. First Cenozoic glaciers in West Antarctica. Polish Polar Research 26:3-12.

Breza, J. R., and S. W. Wise, Jr. 1992. Lower Oligocene ice-rafted debris on the Kerguelen Plateau: Evidence for East Antarctic continental glaciation. In Proceedings of the Ocean Drilling Program, Scientific Results, vol. 120, eds. S. W. Wise, Jr. and R. Schlich, pp. 161-178. College Station, TX: Ocean Drilling Program.

Browning, J. V., K. G. Miller, and D. K. Pak. 1996. Global implications of lower to middle Eocene sequences on the New Jersey coastal plain: The icehouse cometh. Geology 24:639-642.

Browning, J. V., K. G. Miller, P. P. McLaughlin, M. A. Kominz, P. J. Sugarman, D. Monteverde, M. D. Feigenson, and J. C. Hernàndez. 2006. Quantification of the effects of eustasy, subsidence, and sediment supply on Miocene sequences, Mid-Atlantic margin of the United States. Geological Society of America Bulletin 118:567-588.

Christie-Blick, N., G. S. Mountain, and K. G. Miller. 1990. Seismic stratigraphic record of sea-level change. In Sea-Level Change, pp. 116-140. Washington, D.C.: National Academy Press.

Cooper, A. K., and P. E. O'Brien. 2004. Leg 188 synthesis: Transitions in the glacial history of the Prydz Bay region, East Antarctica, from ODP drilling. In Proceedings of the Ocean Drilling Program, Scientific Results, vol. 188, eds. A. K. Cooper, P. E. O'Brien, and C. Richter, pp. 1-42. College Station, TX: Ocean Drilling Program.

Cooper, A. K., G. Brancolini, E. Escutia, Y. Kristoffersen, R. Larter, G. Leitchenkov, P. O'Brien, and W. Jokat. Forthcoming. Cenozoic climate history from seismic-reflection and drilling studies on the Antarctic continental margin. In Antarctic Climate Evolution. Amsterdam: Elsevier.

Coxall, H. K., P. A. Wilson, H. Pälike, C. H. Lear, and J. Backman. 2005. Rapid stepwise onset of Antarctic glaciation and deeper calcite compensation in the Pacific Ocean. Nature 433:53-57.

DeConto, R. M., and D. Pollard. 2003a. A coupled climate-ice sheet modeling approach to the early Cenozoic history of the Antarctic ice sheet. Paleogeography, Paleoclimatology, Paleoecology 198:39-52.

DeConto, R. M., and D. Pollard. 2003b. Rapid Cenozoic glaciation of Antarctica induced by declining atmospheric $\mathrm{CO}_{2}$. Nature 421:245-249.

Diester-Haass, L., and J. Zachos. 2003. The Eocene-Oligocene transition in the Equatorial Atlantic (ODP Site 925); paleoproductivity increase and positive $\delta^{13} \mathrm{C}$ excursion. In Greenhouse to Icehouse: The Marine EoceneOligocene Transition, eds. D. R. Prothero, L. C. Ivany, and E. A. Nesbitt. pp. 397-416, New York: Columbia University Press.

Eldrett, J. S., I. C. Harding, P. A. Wilson, E. Butler, and A. P. Roberts. 2007. Continental ice in Greenland during the Eocene and Oligocene. Science 446:176-179.

Emiliani, C. 1955. Pleistocene temperatures. Journal of Geology 63: 538-578.

Fairbanks, R. G. 1989. A 17,000-year glacio-eustatic sea level record: Influence of glacial melting rates on the Younger Dryas event and deep-ocean circulation. Nature 342:637-642. 
Falkowski, P. G., M. E. Katz, A. Knoll, A. Quigg, J. A. Raven, O. Schofield, and M. Taylor. 2004. The evolutionary history of eukaryotic phytoplankton. Science 305:354-360.

Finkel, Z. V., M. E. Katz, J. D. Wright, O. M. E. Schofield, and P. G. Falkowski. 2005. Climatically-driven evolutionary change in the size of diatoms over the Cenozoic. Proceedings of the National Academy of Sciences U.S.A. 102:8927-8932.

Fitzgerald, P. G. 2002. Tectonics and landscape evolution of the Antarctic plate since Gondwana breakup, with an emphasis on the West Antarctic rift system and the Transantarctic Mountains. In Antarctica at the Close of a Millennium. Proceedings of the 8th International Symposium on Antarctic Earth Science, eds. J. A. Gamble, D. N. B. Skinner, and S. Henrys. Bulletin of the Royal Society of New Zealand 35:453-469.

Flint, R. F. 1971. Glacial and Quaternary Geology. New York: John Wiley.

Francis, J. E., and I. Poole. 2002. Cretaceous and early Tertiary climates of Antarctica: Evidence from fossil wood. Paleogeography, Paleoclimatology, Paleoecology 182:47-64.

Hancock, J. M. 1993. Transatlantic correlations in the Campanian-Maastrichtian stages by eustatic changes of sea-level. In High Resolution Stratigraphy, eds. E. A. Hailwood and R. B. Kidd, pp. 241-256. Geological Society Special Publication.

Haq, B. U., J. Hardenbol, and P. R. Vail. 1987. Chronology of fluctuating sea levels since the Triassic (250 million years ago to present). Science 235:1156-1167.

Hays, J. D., J. Imbrie, and N. J. Shackleton. 1976. Variations in the earth's orbit: Pacemaker of the ice ages. Science 194:1121-1132.

Hedberg, H. D. 1976. International Stratigraphic Guide. New York: Wiley-Interscience.

Huber, B. T., R. D. Norris, and K. G. MacLeod. 2002. Deep sea paleotemperature record of extreme warmth during the Cretaceous. Geology 30:123-126.

Ivany, C. L., S. Van Simaeys, E. W. Domack, and S. D. Samson. 2006. Evidence for an earliest Oligocene ice sheet on the Antarctic Peninsula. Geology 34:377-380.

Kennett, J. P. 1977. Cenozoic evolution of Antarctic glaciation, the CircumAntarctic Ocean, and their impact on global paleoceanography. Journal of Geophysical Research 82:3843-3860.

Kennett, J. P., and P. F. Barker. 1990. Latest Cretaceous to Cenozoic climate and oceanographic developments in the Weddell Sea, Antarctica: An ocean-drilling perspective. In Proceedings of the Ocean Drilling Program, Scientific Results, vol. 113, eds. P. F. Barker and J. P. Kennett, pp. 937-960. College Station, TX: Ocean Drilling Program.

Kennett, J. P., and D. A. Hodell. 1996. Stability or instability of Antarctic ice sheets during warm climates of the Pliocene? GSA Today 5:1-22.

Kennett, J. P., and N. J. Shackleton. 1976. Oxygen isotopic evidence for the development of the psychrosphere $38 \mathrm{Myr}$ ago. Nature 260:513-515.

Kennett, J., and L. Stott. 1990. Proteus and Proto-Oceanus: Ancestral Paleogene oceans as revealed from Antarctic stable isotopic results, ODP Leg 113. In Proceedings ODP Scientific Results, vol. 113, eds. P. Barker and J. Kennett, pp. 865-880. College Station, TX: Ocean Drilling Program.

Kominz, M. A., K. G. Miller, and J. V. Browning. 1998. Long-term and short-term global Cenozoic sea-level estimates. Geology 26:311-314.

Kominz, M. A., J. V. Browning, K. G. Miller, P. J. Sugarman, S. Mizintseva, A. Harris, and C. R. Scotese. In review. Late Cretaceous to Miocene sea-level estimates from the New Jersey and Delaware coastal plain coreholes: An error analysis. Basin Research.

Larsen, H. C., A. D. Saunders, P. D. Clift, J. Beget, W. Wei, S. Spezzaferri, and ODP Leg 152 Scientific Party. 1994. Seven million years of glaciation in Greenland. Science 264:952-955.

Lear, C. H., and Y. Rosenthal. 2006. Benthic foraminiferal Li/Ca: Insights into Cenozoic seawater carbonate saturation state. Geology 34:985-988.
Leckie, M., and P.-N. Webb. 1986. Late Paleogene and early Neogene foraminifers of Deep Sea Drilling Project Site 270, Ross Sea, Initial Reports DSDP 90:1093-1142. Washington, D.C.: U.S. Government Printing Office.

LeMasurier, W. E., and D. C. Rex. 1982. Volcanic record of Cenozoic glacial history in Marie Byrd Land and western Ellsworth Land: Revised chronology and evaluation of tectonic factors. In Antarctic Geoscience, ed. C. Craddock, pp. 725-732. Madison: University of Wisconsin Press.

Mancini, E. A., and B. H. Tew. 1995. Geochronology, biostratigraphy and sequence stratigraphy of a marginal marine to marine shelf stratigraphic succession: Upper Paleocene and lower Eocene, Wilcox Group, eastern Gulf Coastal Plain, U.S.A. In Geochronology, Time Scales and Global Stratigraphic Correlations: A Unified Temporal Framework for an Historical Geology, eds. W. A. Berggren, D. V. Kent, M.-P. Aubry, and J. Hardenbol, pp. 281-293. Special Publication 54. Tulsa, OK: Society for Sedimentary Geology.

Marchant, D. R., G. H. Denton, and C. C. Swisher. 1993. Miocene-PliocenePleistocene glacial history of Arena Valley, Quartermain Mountains, Antarctica. Geografiska Annaler 75A:269-302.

Margolis, S. V., and J. P. Kennett. 1971. Cenozoic paleoglacial history of Antarctica recorded in subantarctic deep-sea cores. American Journal of Science 271:1-36.

Matthews, R. K. 1984. Oxygen-isotope record of ice-volume history: 100 million years of glacio-eustatic sea-level fluctuation. Memoirs of the American Association of Petroleum Geologists 36:97-107.

Matthews, R. K., and C. Frohlich. 2002. Maximum flooding surfaces and sequence boundaries: Comparisons between observations and orbital forcing in the Cretaceous and Jurassic (65-190 Ma). GeoArabia 7:503-538.

Matthews, R. K., and R. Z. Poore. 1980. Tertiary $\delta^{18} \mathrm{O}$ record and glacioeustatic sea-level fluctuations. Geology 8:501-504.

Miall, A. D. 1991. Stratigraphic sequences and their chronostratigraphic correlation. Journal of Sedimentary Petrology 61:497-505.

Miller, K. G. 1992. Middle Eocene to Oligocene stable isotopes, climate, and deep-water history: The Terminal Eocene Event? In Eocene-Oligocene Climatic and Biotic Evolution, eds. D. Prothero and W. A. Berggren, pp. 160-177. Princeton: Princeton University Press.

Miller, K. G., and R. G. Fairbanks. 1983. Evidence for Oligocene-middle Miocene abyssal circulation changes in the western North Atlantic. Nature 306:250-252.

Miller, K. G., and R. G. Fairbanks. 1985. Oligocene to Miocene carbon isotope cycles and abyssal circulation changes. In The Carbon Cycle and Atmospheric CO2: Natural Variations Archean to Present, eds. E. T. Sundquist and W. S. Broecker, pp. 469-486. Washington, D.C.: American Geophysical Union.

Miller, K. G., and M. E. Katz. 1987. Oligocene-Miocene benthic foraminiferal and abyssal circulation changes in the North Atlantic. Micropaleontology 33:97-149.

Miller, K. G., and B. E. Tucholke. 1983. Development of Cenozoic abyssal circulation south of the Greenland-Scotland Ridge. In Structure and Development of the Greenland-Scotland Ridge, eds. M. H. P. Bott, S. Saxov, M. Talwani, and J. Thiede, pp. 549-589. New York: Plenum Press.

Miller, K. G., R. G. Fairbanks, and G. S. Mountain. 1987. Tertiary oxygen isotope synthesis, sea level history, and continental margin erosion. Paleoceanography 2:1-19.

Miller, K. G., J. D. Wright, and R. G. Fairbanks. 1991. Unlocking the Ice House: Oligocene-Miocene oxygen isotopes, eustasy, and margin erosion. Journal of Geophysical Research 96:6829-6848.

Miller, K. G., G. S. Mountain, the Leg 150 Shipboard Party, and Members of the New Jersey Coastal Plain Drilling Project. 1996. Drilling and dating New Jersey Oligocene-Miocene sequences: Ice volume, global sea level, and Exxon records. Science 271:1092-1094.

Miller, K. G., G. S. Mountain, J. V. Browning, M. A. Kominz, P. J. Sugarman, N. Christie-Blick, M. E. Katz, and J. D. Wright. 1998. Cenozoic global sea-level, sequences, and the New Jersey transect: Results from coastal plain and slope drilling. Reviews of Geophysics 36:569-601. 
Miller, K. G., E. Barrera, R. K. Olsson, P. J. Sugarman, and S. M. Savin. 1999. Does ice drive early Maastrichtian eustasy? Geology 27:783-786.

Miller, K. G., P. J. Sugarman, J. V. Browning, M. A. Kominz, J. C. Hernàndez, R. K. Olsson, J. D. Wright, M. D. Feigenson, and W. Van Sickel. 2003. Late Cretaceous chronology of large, rapid sea-level changes: Glacioeustasy during the greenhouse world. Geology 31:585-588.

Miller, K. G., P. J. Sugarman, J. V. Browning, M. A. Kominz, R. K. Olsson, M. D. Feigenson, and J. C. Hernàndez. 2004. Upper Cretaceous sequences and sea-level history, New Jersey coastal plain. Geological Society of America Bulletin 116:368-393.

Miller, K. G., M. A. Kominz, J. V. Browning, J. D. Wright, G. S. Mountain, M. E. Katz, P. J. Sugarman, B. S. Cramer, N. Christie-Blick, and S. F. Pekar. 2005a. The Phanerozoic record of global sea-level change. Science 310:1293-1298.

Miller, K. G., J. D. Wright, and J. V. Browning. 2005b. Visions of ice sheets in a greenhouse world. Marine Geology 217:215-231.

Miller, K. G., J. V. Browning, M.-P. Aubry, B. S. Wade, M. E. Katz, A. A Kulpecz, and J. D. Wright. 2008. Eocene-Oligocene global climate and sea-level changes: St. Stephens Quarry, Alabama. Geological Society of America Bulletin 120:34-53.

Moore, T. C., Jr., J. Backman, I. Raffi, C. Nigrini, A. Sanfilippo, H. Pälike, and M. Lyle. 2004. Paleogene tropical Pacific: Clues to circulation, productivity and plate motion. Paleoceanography 19 , doi:10.1029/2003PA000998.

Moran, K., J. Backman, H. Brinkhuis, S. C. Clemens, T. Cronin, G. R. Dickens, F. Eynaud, J. Gattacceca, M. Jakobsson, R. W. Jordan, M. Kaminski, J. King, N. Koc, A. Krylov, N. Martinez, J. Matthiessen, D. McInroy, T. M. Moore, J. Onodera, M. O'Regan, H. Palike, B. Rea, D. Rio, T. Sakamoto, D. C. Smith, R. Stein, K. St John, I. Suto, N. Suzuki, K. Takahashi, M. Watanabe, M. Yamamoto, J. Farrell, M. Frank, P. Kubik, W. Jokat, and Y. Kristoffersen. 2006. The Cenozoic palaeoenvironment of the Arctic Ocean. Nature 441:601-605.

Moriya, K., P. A. Wilson, O. Friedrich, J. Erbacher, and H. Kawahata. 2007. Testing for ice sheets during the mid-Cretaceous greenhouse using glassy foraminiferal calcite from the mid-Cenomanian tropics on Demerara Rise. Geology 35:615-618.

Mountain, G. S., and K. G. Miller. 1992. Seismic and geologic evidence for early Paleogene deep-water circulation in the western North Atlantic. Paleoceanography 7:423-439.

Pagani, M., J. Zachos, K. H. Freeman, S. Bohaty, and B. Tipple. 2005. Marked change in atmospheric carbon dioxide concentrations during the Oligocene. Science 309:600-603.

Pak, D. K., and K. G. Miller. 1992. Paleocene to Eocene benthic foraminiferal isotopes and assemblages: Implications for deepwater circulation. Paleoceanography 7:405-422.

Pekar, S., and K. G. Miller. 1996. New Jersey Oligocene "Icehouse" sequences (ODP Leg 150X) correlated with global $\delta^{18} \mathrm{O}$ and Exxon eustatic records. Geology 24:567-570.

Pekar, S. F., N. Christie-Blick, M. A. Kominz, and K. G. Miller. 2002. Calibration between eustatic estimates from backstripping and oxygen isotopic records for the Oligocene. Geology 30:903-906.

Peltier, W. R. 1997. Postglacial variations in the level of the sea: Implications for climate dynamics and solid-earth geophysics. Reviews of Geophysics 36:603-689.

Pitman, W. C., III, and X. Golovchenko. 1983. The effect of sea-level change on the shelf edge and slope of passive margins. Special Publication 33, pp. 41-58. Society of Economic Paleontologists and Mineralogists.

Rea, D. K., and M. W. Lyle. 2005. Paleogene calcite compensation depth in the eastern 340 subtropical Pacific; answers and questions. Paleoceanography 20:1-9.

Robert, C., and J. P. Kennett. 1997. Antarctic continental weathering changes during Eocene-Oligocene cryosphere expansion: Clay mineral and oxygen isotope evidence Geology 25:587-590.
Royer, D., R. A. Berner, I. P. Montanez, N. J. Tabor, and D. J. Beerling. 2004. CO2 as a primary driver of Phanerozoic climate. GSA Today 14:4-10.

Sahagian, D., O. Pinous, A. Olferiev, V. Zakaharov, and A. Beisel. 1996. Eustatic curve for the Middle Jurassic-Cretaceous based on Russian platform and Siberian stratigraphy: Zonal resolution. American Association of Petroleum Geologists Bulletin 80:1433-1458.

Salamy, K. A., and J. C. Zachos. 1999. Late Eocene-Early Oligocene climate change on southern ocean fertility: Inferences from sediment accumulation and stable isotope data. Paleogeography, Paleoclimatology, Paleoecology 145:79-93.

Savin, S. M., R. G. Douglas, and F. G. Stehli. 1975. Tertiary marine paleotemperatures. Geological Society of America Bulletin 86:1499-1510.

Shackleton, N. J. 1967. Oxygen isotope analyses and Pleistocene temperatures re-assessed. Nature 215:15-17.

Shackleton, N. J., and J. P. Kennett. 1975. Paleotemperature history of the Cenozoic and the initiation of Antarctic glaciation, oxygen and carbon isotope analyses in DSDP sites 277, 279, and 281. In Init. Reports DSDP, eds. J. P. Kennett, R. E. Houtz et al., pp. 743-755. Washington, D.C.: U.S. Government Printing Office.

Shackleton, N. J., J. Backman, H. Zimmerman, D. V. Kent, M. A. Hall, D. G. Roberts, D. Schnitker, J. G. Baldauf, A. Desprairies, R. Homrighausen, P. Huddlestun, J. B. Keene, A. J. Kaltenback, K. A. O. Krumsiek, A. C. Morton, J. W. Murray, and J. Westberg-Smith. 1984. Oxygen isotope calibration of the onset of ice-rafting and history of glaciation in the North Atlantic region. Nature 307:620-623.

Stoll, H. M., and D. P. Schrag. 1996. Evidence for glacial control of rapid sea level changes in the Early Cretaceous. Science 272:1771-1774.

Stoll, H. M., and D. P. Schrag. 2000. High resolution stable isotope records from the Upper Cretaceous rocks of Italy and Spain: Glacial episodes in a greenhouse planet? Geological Society of America Bulletin 112:308-319.

Strand, K., S. Passchier, and J. Nasi. 2003. Implications of quartz grain microtextures for onset Eocene/Oligocene glaciation in Prydz Bay, ODP Site 1166, Antarctica. Paleogeography, Paleoclimatology, Paleoecology 198:101-111.

Suko, I. 2006. The explosive diversification of the diatom genus Chaetoceros across the Eocene/Oligocene and Oligocene/Miocene boundaries in the Norwegian Sea. Marine Micropaleontology 58:259-269.

ten Brink, U., R. Hackney, S. Bannister, T. Stern, and Y. Makovsky. 1997. Uplift of the Transantarctic Mountains and the bedrock beneath the East Antarctic ice sheet. Journal of Geophysical Research 102: 27603-27621.

Thomas, E., ed. 1990. Late Cretaceous through Neogene Deep-Sea Benthic Foraminifers (Maud Rise, Weddell Sea, Antarctica). College Station, TX: Ocean Drilling Program.

Thorne, J. A., and A. B. Watts. 1984. Seismic reflectors and unconformities at passive continental margins. Nature 311:365-368.

Thunell, R. C., and B. H. Corliss. 1986. Late Eocene-early Oligocene carbonate sedimentation in the deep sea. In Terminal Eocene Events, eds. C. Pomerol and I. Premoli-Silva, pp. 363-380. Amsterdam: Elsevier.

Tripati, A., J. Backman, H. Elderfield, and P. Ferretti. 2005. Eocene bipolar glaciation associated with global carbon cycle changes. Nature 436:341-346.

Troedson, A. L., and J. B. Riding. 2002. Upper Oligocene to lowermost Miocene strata of King George Island, South Shetland Islands, Antarctica: Stratigraphy, facies analysis and implications for the glacial history of the Antarctic Peninsula. Journal of Sedimentary Research 72:510-523.

Troedson, A. L., and J. L. Smellie. 2002. The Polonez Cove Formation of King George Island, Antarctica: Stratigraphy, facies and implications for mid-Cenozoic cryosphere development. Sedimentology 49:277-301.

Tucholke, B. E., and G. S. Mountain. 1979. Seismic stratigraphy, lithostratigraphy and paleosedimentation patterns in the North American basin. In Deep Drilling Results in the Atlantic Ocean: Continental Margins and Paleoenvironment, eds. M. W. Talwani, W. Hay, and W. B. F. Ryan, pp. 58-86. Washington, D.C.: American Geophysical Union. 
Vail, P. R., R. M. Mitchum, R. G. Todd, J. M. Widmier, S. Thompson III, J. B. Sangree, J. N. Bubb, and W. G. Hatlelid. 1977. Seismic stratigraphy and global changes of sea level. In Seismic Stratigraphy-Applications to Hydrocarbon Exploration, ed. C. E. Payton. Memoirs of the American Association of Petroleum Geologists 26:49-205. Tulsa, OK: AAPG.

van Andel, T. H. 1975. Mesozoic/Cenozoic calcite compensation depth and global distribution of calcareous sediments. Earth and Planetary Science Letters 26:187-194.

Van Sickel, W. A., M. A. Kominz, K. G. Miller, and J. V. Browning. 2004. Late Cretaceous and Cenozoic sea-level estimates: Backstripping analysis of borehole data, onshore New Jersey. Basin Research 16:451-465.

Wade, B. S., and H. Pälike. 2004. Oligocene climate dynamics. Paleoceanography 19:PA4019. doi:10.1029/2004PA001042.

Wei, W. 1992. Calcareous nannofossil stratigraphy and reassessment of the Eocene glacial record in subantarctic piston cores of the southeast Pacific. In Proceedings of the ODP Scientific Results, eds. S. W. Wise, Jr. and R. Schlich, pp. 1093-1104. College Station, TX: Ocean Drilling Program.

Williams, R. S., and J. G. Ferrigno. 1995. Satellite image atlas of glaciers of the world-Greenland. U.S. Geological Survey Professional Paper 1386-C: 141 pp, http://pubs.usgs.gov/pp/p1386c/p1386c.pdf.
Wise, S. W., Jr., J. R. Breza, D. M. Harwood, and W. Wei. 1991. Paleogene glacial history of Antarctica. In Controversies in Modern Geology: Evolution of Geological Theories in Sedimentology, Earth History and Tectonics, eds. D. W. Miller, J. A. McKenzie, and H. Weissert, pp. 133171. London: Academic Press.

Wright, J. D., and K. G. Miller. 1996. Control of North Atlantic deep water circulation by the Greenland-Scotland Ridge. Paleoceanography 11:157-170.

Zachos, J. C., J. Breza, and S. W. Wise. 1992. Earliest Oligocene ice-sheet expansion on East Antarctica: Stable isotope and sedimentological data from Kerguelen Plateau. Geology 20:569-573.

Zachos, J. C., L. D. Stott, and K. C. Lohmann. 1994. Evolution of early Cenozoic marine temperatures. Paleoceanography 9:353-387.

Zachos, J. C., T. M. Quinn, and K. A. Salamy. 1996. High resolution (104 yr) deep-sea foraminiferal stable isotope records of the earliest Oligocene climate transition. Paleoceanography 9:353-387. 